\title{
Klauzula sumienia realizowana w prawie zawodów medycznych w Polsce w kontekście realizacji Europejskiej Konwencji praw człowieka
}

\section{Clause of conscience implemented in competition law medical in Poland in the context of the implementation of the European Convention On Human Rights}

\author{
Iwona Radlińska, Marcin Kolwitz \\ Katedra i Zakład Zdrowia Publicznego Pomorskiego Uniwersytetu Medycznego w Szczecinie \\ ul. Żołnierska 48, 71-210 Szczecin \\ Kierownik: prof. dr hab. n. zdr. Beata Karakiewicz
}

\section{SUMMARY}

Freedom of conscience and religion, also called conscience clause legislation is part of the inherent and inalienable rights of every human being and freedoms protected by the constitution as a fundamental principle of democratic countries working in the law. At international level, the most common piece of legislation on this issue is the European Convention on Human Rights of 4 November 1950, which Poland is a party. Pursuant to Art. 9 of the European Convention Poland is committed to the protection of freedom of thought, conscience and religion to every person under its jurisdiction, including the medical professions. In a special way to be protected by the freedom of conscience of physicians, dentists, nurses and midwives, as the conscience clause is written in the law governing the exercise of such professions in Poland.

Key words: conscience clause, European Convention on Human Rights, freedoms and rights, abortion, medical professions.

\section{STRESZCZENIE}

Wolność sumienia i wyznania nazywana jest w prawodawstwie także klauzulą sumienia. Jest częścią przyrodzonych i niezbywalnych każdemu człowiekowi wolności i praw, które jako podstawowa zasada funkcjonująca w demokratycznych państwach prawnych chronione są przez konstytucje. Na poziomie międzynarodowym najbardziej powszechnym aktem prawnym dotyczącym tego zagadnienia jest Europejska konwencja praw człowieka z 4 listopada 1950 r., której Polska jest stroną. Na mocy art. 9 Konwencji europejskiej Polska zobowiązała się do ochrony wolności myśli, sumienia i wyznania każdej osoby podlegającej jej jurysdykcji, w tym zawodom medycznym. W szczególny sposób powinna być chroniona wolność sumienia lekarzy, lekarzy dentystów, pielęgniarek i położnych, gdyż klauzula sumienia jest wpisana w prawo regulujące wykonywanie tych zawodów w Polsce.

Słowa kluczowe: klauzula sumienia, Europejska konwencja praw człowieka, wolności i prawa, aborcja, zawody medyczne.

\section{ŹRÓDŁA PRAWNE KLAUZULI SUMIENIA}

Klauzula sumienia jest terminem używanym w prawie do określenia wolności człowieka do wyznawania swoich przekonań wynikających z religii czy wrażliwości sumienia. Wolność przekonań i wyznania zaliczana jest do praw człowieka chronionych w konstytucjach. Pierwotnym źródłem ochrony praw człowieka nie są jednak akty prawne, nawet rangi konstytucyjnej. Ochrona ta wypływa z godności człowieka. Akty prawne umożliwiają jedynie realizację tych wolności, chroniąc człowieka przed działaniami jednostek, grup, a nawet państw, które naruszają te prawa. Zgodnie z art. 30 Konstytucji Rzeczypospolitej Polskiej: „Przyrodzona i niezbywalna godność człowieka stanowi źródło wolności i praw człowieka i obywatela. Jest ona nienaruszalna, a jej poszanowanie i ochrona jest obowiązkiem władz publicznych" [1]. Wynika zatem z tego zapisu, że sam fakt bycia osobą ludzką i obywatelem danego państwa daje prawo do ochrony. Państwo polskie zobowiązuje się więc na pierwszym miejscu do poszanowania wolności i praw jednostki oraz niewkraczania w sferę je obejmującą bez podstawy prawnej (np. ochrona miru domowego oznacza niewchodzenie do czyjegoś domu bez nakazu). W przypadku naruszenia wolności i praw państwo zapewnia jednostce ochronę prawną (dostęp do sądu, realizacja sankcji prawnych itd.). Spisanie praw człowieka w akcie prawnym gwarantuje więc, że bez względu na polityczne zmiany układów władzy w państwie władze te są zobowiązane do przestrzegania praw.

Kwestia wolności sumienia i wyznania w Konstytucji RP znajduje też odzwierciedlenie w zasadzie demokratycznego państwa prawa (art. 2: „Rzeczpospolita Polska jest demokratycznym państwem prawnym, urzeczywistniającym zasady sprawiedliwości społecznej") [1]. Zasada ta ma oznaczać w praktyce, że prawo stoi ponad państwem i reprezentującymi je urzędnikami. 
Inną kluczową zasadą konstytucyjną w tym zakresie jest zasada legalizmu z art. 7 Konstytucji RP, mówiąca o tym, że organy władzy publicznej działają na podstawie prawa i w jego granicach. Oznacza to, że organ władzy państwowej działa tylko wówczas, gdy prawo mu na to dozwoli (konkretny akt prawny), a co nie jest mu dozwolone, jest bezwzględnie zakazane. Tymczasem działanie jednostki podlega całkiem odmiennej zasadzie - co nie jest zabronione, jest dozwolone czyli człowiek może czynić wszystko, czego prawo mu wyraźnie nie zakazuje [2]. Zgodnie więc z Konstytucją RP ograniczenia w zakresie korzystania z wolności i praw człowieka mogą być ustanawiane tylko w najwyższym po Konstytucji akcie prawnym, jakim jest ustawa, i nie mogą naruszać istoty wolności i praw (art. 31). Przesłankami wprowadzenia ograniczeń w zakresie korzystania z konstytucyjnych wolności i praw są: „zapewnienie bezpieczeństwa lub porządku publicznego, ochrony środowiska, zdrowia i moralności publicznej, czy wolności i praw innych osób”. Jest to katalog zamknięty, jednak zawierający pojęcia nieostre, co może niewątpliwie stwarzać pole do interpretacji i poszerzać możliwość stosowania ograniczeń w korzystaniu z wolności i praw konstytucyjnych. Zasady prawne dotyczące ingerencji państwa we wspominaną sferę powinny więc być respektowane i w razie nieprawnego działania organy państwa muszą odpowiedzieć za naruszenia zgodnie z art. 77 Konstytucji RP: „Każdy ma prawo do wynagrodzenia szkody, jaka została mu wyrządzona przez niezgodne z prawem działanie organu władzy publicznej" [1].

Aktem prawnym o zasięgu międ zynarodowym, zapewniającym ochronę wolności i praw człowieka, w tym jego wolności przekonań i wyznania, jest Konwencja o ochronie praw człowieka i podstawowych wolności z 4 listopada 1950 r., nazywana najczęściej Europejską konwencją praw człowieka (w tekście dalej nazywana „Konwencją europejską”). Konwencja europejska jest umową międzynarodową podpisaną 4 listopada $1950 \mathrm{r}$. przez państwa członkowskie Rady Europy. Jej wejście w życie wymaga ratyfikacji państw członkowskich. Polska stała się stroną Konwencji europejskiej w 1993 r. Zgodnie z preambułą konwencja jest prawnym wypełnieniem zapisów Powszechnej deklaracji praw człowieka uchwalonej 10 grudnia 1948 r. przez Zgromadzenie Ogólne Narodów Zjednoczonych. Deklaracja nie miała bowiem mocy prawnej, ale (jak sama nazwa wskazuje) w dokumencie tym jedynie zadeklarowano określone wartości, jakimi są prawa człowieka.

W art. 1 Deklaracji można przeczytać: „Wszyscy ludzie rodzą się wolni i równi pod względem swej godności i swych praw. Są oni obdarzeni rozumem i sumieniem (...)”. Bezpośrednio wolności sumienia dotyczy art. 18: „Każdy człowiek ma prawo do wolności myśli, sumienia i wyznania”. Ta deklaracja została wiernie powtórzona w Konwencji praw człowieka.

Tymczasem Konwencja stworzyła katalog praw chronionych sankcjami stosowanymi przez ustanowiony w Konwencji sąd międzynarodowy. Zgodnie bowiem z Konwencją europejską nieprzestrzeganie jej postanowień skutkuje odpowiedzialnością przed Europejskim Trybunałem praw człowieka (nazywany dalej „Trybunałem Europejskim”). Przystąpienie do Konwencji europejskiej, jak do każdej umowy międzynarodowej, jest dobrowolne, jednak jej ratyfikacja skutkuje prawnym zobowiązaniem do jej przestrzegania i honorowania wyroków Trybunału Europejskiego (czyli zapłacenia kary zasądzonej wyrokiem przez państwo będące stroną Konwencji europejskiej). Artykuł 9 Konwencji europejskiej reguluje prawo każdego człowieka do wolności myśli, sumienia i wyznania. Prawo to obejmuje wolności: zmiany wyznania lub przekonań oraz uzewnętrzniania (indywidualnie albo wspólnie z innymi, publicznie lub prywatnie) swego wyznania i przekonań przez uprawianie kultu, nauczanie, praktykowanie oraz czynności rytualne. Prawo to obejmuje co do zasady również dzieci, jednak powszechnie w konstytucjach państw uznaje się, że wolność sumienia, wyznania i przekonań rodziców obejmuje ich prawo do wychowania dzieci zgodnie z wyznawanymi wartościami z uwzględnieniem stopnia dojrzałości dziecka i jego z wiekiem kształtujących się przekonań. Reguluje to np. art. 48 Konstytucji RP [1].

Wolność przekonań, w tym sumienia i wyznania, może być rozpatrywana w dwóch płaszczyznach, wewnętrznej i zewnętrznej [3, 4]. Płaszczyzna wewnętrzna obejmuje tzw. wolność duchową, tj. możliwość sformułowania swojej hierarchii wartości, tworzenia własnego światopoglądu, a ostatecznie wolność w określenia sensu i celu swojego życia [5]. „Wolność duchowa” oznacza szczególnie prawo do zdefiniowania, co jest dobre, a co złe, i prawo swobodnego podążania za tym, co jest dobre. Ta sfera wewnętrznej autonomii jednostki (forum internum) nie może podlegać żadnym ograniczeniom, tj. ma wymiar absolutny ze względu na to, że dotyczy płaszczyzny duchowej $[6,7]$.

Płaszczyzna wewnętrzna wolności podlega jednak pewnym ograniczeniom w momencie jej ekspresji na zewnątrz, ze względu na fakt życia człowieka w społeczeństwie. Wówczas mamy już do czynienia z aspektem zewnętrznym wolności przekonań i wyznania (forum externum), która oznacza, że każdy ma prawo uzewnętrzniania swojego wyznania lub przekonań, a w szczególności do postępowania zgodnie z nakazem sumienia [8]. Konwencja europejska formułuje ten aspekt wolności jako wolność uzewnętrzniania przekonań w art. 9 ust. 2, która „może podlegać jedynie takim ograniczeniom, które są przewidziane prawem i są konieczne w społeczeństwie demokratycznym z uwagi na interesy bezpieczeństwa publicznego, ochronę porządku publicznego, zdrowia i moralności lub ochronę praw i wolności innych osób". Przesłanki te są w zasadzie zbieżne z przesłankami ingerencji zapisanymi w Konstytucji RP (omawiany art. 31 Konstytucji RP). W podręczniku praw człowieka Rady Europy opublikowanym w 2012 r. zawarto listę kluczowych pytań dotyczących zasadności stosowania art. 9. Odpowiedzi na te pytania dają jednoznaczną ocenę problemu, czy wprowadzenie przez państwo ograniczenia wolności sumienia i wyznania było uzasadnione czy też nie, a także, czy inny niż państwo podmiot prawny łamie wolność. Są to pytania wykorzystywane w pracy orzeczniczej Trybunału Europejskiego, ale również i państwo zanim wprowadzi ograniczenie wolności sumienia i wyznania, winno je sobie zadać, aby uniknąć roszczeń odszkodowawczych z tytułu naruszenia art. 9 Konwencji europejskiej. Pytania są omawiane na podstawie bogatego orzecznictwa Trybunału Europejskiego 
i mają następującą treść: Jaki jest zakres każdej z gwarancji? Czy miała miejsce ingerencja w gwarantowane prawo? Czy ingerencja ma uzasadniony cel? Czy ingerencja pozostaje „w zgodzie z prawem”? Czy ingerencja jest „konieczna w społeczeństwie demokratycznym"?

Dwa pierwsze pytania odnoszą się do zbadania treści wolności sumienia z art. 9 Konwencji europejskiej. Odpowiedź na nie zawiera takie elementy, jak zdefiniowanie wolności będącej przedmiotem skargi jako części wolności „myśli, sumienia i wyznania" w aspekcie wewnętrznym bądź zewnętrznym, indywidualnym bądź zbiorowym, a także zakres wprowadzonego przez państwo ograniczenia wolności [7].

Wobec faktu trudności w jednoznacznym zdefiniowaniu przesłanek ingerencji w sferę wolności przekonań i wyznania (nieostrość wyrażenia) w art. 9 ust. 2 Konwencji europejskiej obejmującym bezpieczeństwo publiczne, ochronę porządku publicznego, zdrowia i moralności oraz ochronę praw i wolności innych osób (o czym była już była mowa na przykładzie Konstytucji RP), możliwa jest ich zbyt szeroka interpretacja, która może prowadzić do nadużycia. Z praktyki orzeczniczej Trybunału Europejskiego wynika, że jeżeli dowiedzie się, że „ingerencja” miała miejsce (odpowiedź pozytywna na dwa pierwsze pytania), ciężar wykazania, że była ona uzasadniona, spoczywa na zaskarżonym państwie. Musi ono odpowiedzieć na pozostałe pytania stanowiących potrójny test: celowości, legalności i konieczności.

Pozytywna odpowiedź na pytanie, czy ingerencja ma uzasadniony cel, zazwyczaj nie stanowi problemu dla pozwanego państwa. Państwo musi wskazać jedną bądź więcej przesłanek wprowadzenia ograniczeń spośród wymienionych w art. 9 ust. 2 Konwencji europejskiej, stanowiących cele ingerencji. Taką przesłanką może być fakt, że w sytuacji zagrożenia życia ludzkiego lekarz nie może swobodnie dysponować wolnością sumienia. Przesłanki te stanowią katalog zamknięty, dlatego ograniczenie wolności „myśli, sumienia i wyznania” może nastąpić tylko w celu ochrony bezpieczeństwa i porządku publicznego, zdrowia i moralności lub praw i wolności innych osób. Jak jednak wcześniej wskazano, są to pojęcia niejednoznaczne. Hamulcem do poszerzania zakresu zastosowania tych definicji są pozostałe prawa wynikające z Konwencji europejskiej, w szczególności art. 8 (prawo do poszanowania życia prywatnego i rodzinnego), art. 10 (wolność wyrażania opinii) i art. 11 (wolność zgromadzeń). Przykładowo ochrona bezpieczeństwa publicznego nie może doprowadzić do zakazu zgromadzeń, a ochrona zdrowia do nakazu wykonania decyzji lekarskich z pominięciem woli pacjenta.

Następnie należy rozpatrzyć kryterium legalności ingerencji państwa w sferę wolności. Odpowiedź na pytanie, czy ingerencja pozostaje „w zgodzie z prawem”, w pierwszym rzędzie sprowadza się do wskazania adekwatnej podstawy prawnej umożliwiającej państwu wprowadzenie ograniczenia wolności. Z orzecznictwa Trybunału Europejskiego wynika, że regulacje te powinny zawierać precyzyjnie określone kryteria, na podstawie których zainteresowany podmiot może ocenić prawdopodobieństwo ingerencji przez państwo, a także precyzyjny opis zachowań, które jednostka może podejmować. Oprócz tego z regulacjami powinny również być związane instrumenty prawne obrony przed arbitralnością władzy publicznej.

Ostatnim kryterium oceny wprowadzania ograniczeń wolności przekonań i wyznania jest kryterium konieczności, inaczej niezbędności ingerencji państwa w sferę wolności. Odpowiadamy zatem na kolejne pytanie o to, czy ingerencja jest „konieczna w społeczeństwie demokratycznym”? Dwa elementy tego pytania są istotne. Wymóg konieczności wprowadzenia ograniczenia wolności oznacza, że państwo musi wprowadzić dane ograniczenie, co jest niezbędne dla zapewnienia bezpieczeństwa i porządku społeczeństwa demokratycznego oraz jego ochrony. Należy jednak pamiętać o najistotniejszych cechach społeczeństwa demokratycznego, do których należy, jak wynika z orzecznictwa Trybunału Europejskiego, pluralizm, tolerancja i otwarty umysł. W szczególności zachowanie pluralizmu jest związane ze swobodnym wyrażaniem wolności sumienia czy wyznania. Artykuł 9 może także wymagać, aby na dostrzeżone zagrożenie nieporządku społecznego zareagować środkami, które raczej promują niż podkopują pluralizm; pomimo że ten sam pluralizm może być innym razem powodem zagrożenia porządku publicznego, co wymagać będzie interwencji państwa. Państwo winno zatem stać się raczej organizatorem i obserwatorem praktykowania różnych religii, wyznań czy przekonań, niż podejmować działania mające na celu ocenę legalności przekonań religijnych, czy sposobów, w jaki one są wyrażane. Szczególną rolą organów władzy nie jest usunięcie przyczyny napięcia poprzez ingerencję służącą wyeliminowanie pluralizmu wyznaniowego, lecz zapewnienie, iż konkurujące grupy tolerują się wzajemnie [9]. Te tezy Trybunału w innym świetle stawiają prawa obywateli państwa pluralistycznego, którzy mają prawo do urzeczywistnienia i ochrony swoich wolności przez odpowiednią organizację systemu społecznego, w jakim żyją, bez względu na spełniane przez nich role społeczne. Należy dodać, że państwo ma pewną swobodę w stosowaniu kryterium konieczności wprowadzenia ograniczeń wolności przekonań w postaci tzw. marginesu swobody państwa uznanego przez Trybunał Europejski [10]. Margines ten oznacza, że dane państwo samo najlepiej jest w stanie ocenić, jaka limitacja jest potrzebna w społeczeństwie demokratycznym. Nawet ocena trybunałów międzynarodowych może być tu zawodna, jednak działania państwa muszą być podjęte w celu zapewnienie utrzymania w nim demokracji, a w ramach niej pluralizmu wyznań i przekonań.

\section{PRAWO ZAWODÓW MEDYCZNYCH DO KLAUZULI SUMIENIA}

Wolność przekonań i wyznania jest wolnością, z której mogą korzystać również kadry medyczne podczas wykonywania czynności zawodowych. Dotyczy to w szczególności lekarzy i pielęgniarek (ze względu na rodzaj udzielanych świadczeń). Zadaniem państwa w myśl zasady pluralizmu światopoglądowego jest zapewnienie wierności swoim przekonaniom również i tej grupie zawodowej. Jak uznał Trybunał Europejski, „osoby, które ze względu na utrwalone przekonania znajdują 
się w sytuacji poważnego konfliktu wynikającego z jednej strony z perspektywy obowiązku służby, a z drugiej strony z ich szerszych przekonań, mają prawo do odwołania się do art. 9 Konwencji" [11]. Oznacza to korzystanie z ochronnej klauzuli wolności przekonań również w ramach stosunku ścisłego podporządkowania w ramach wykonywanej pracy i możliwości uchylenia się od obowiązków zawodowych sprzecznych z sumieniem. Zatem z klauzuli sumienia wynikającej z art. 9 Konwencji może w pełni korzystać personel medyczny. Jednocześnie pacjent ma prawo do uzyskania prawnie dozwolonych świadczeń opieki zdrowotnej, a zapewnienie ich jest obowiązkiem stojącym po stronie państwa. Odmowa udzielenia świadczeń przez lekarza powołującego się na klauzulę sumienia winna być respektowana przez same państwo, które z kolei powinno zapewnić uzyskanie świadczeń przez pacjenta u innego świadczeniodawcy.

Praktyka orzecznicza Trybunału Europejskiego wprowadziła jednak pewne ograniczenia stosowania wolności sumienia w sytuacji, gdy związek między określoną praktyką a racjami czyniącymi zasadne odwołanie się przez jednostkę do klauzuli sumienia nie istniał albo był znacznie osłabiony. Przykładem jest orzeczenie Trybunału Europejskiego mające wpływ na stosowanie klauzuli sumienia i wskazujące, że podatnikowi nie przysługuje prawo do odmowy płacenia podatków nawet w sytuacji, gdy podatki są przeznaczone na procedury niezgodne z jego sumieniem [12]. Również w decyzji z 2001 r. Trybunał uznał, że farmaceuta nie może odwoływać się do klauzuli sumienia w związku z wykonywaniem obowiązków zawodowych, jakim jest sprzedaż leków, w tym antykoncepcyjnych, gdyż z jednej strony prowadzi to do narzucania swoich poglądów religijnych, a z drugiej do uniemożliwienia zakupu legalnego środka w aptece [13]. Jednocześnie trybunał podkreślił, że farmaceuta ma pełne prawo w różny sposób manifestować swoje poglądy, byle nie ograniczać pacjenta w korzystaniu z jego praw. Należy jednak podkreślić, że orzeczenia Trybunału Europejskiego nie są prawotwórcze, tak więc każdorazowo sprawa jest badana z punktu wyjściowego; czy ograniczenie wolności sumienia przez ustawę było prawidłowe, ocenia się z zastosowaniem wspomnianych 5 pytań, w szczególności kryterium konieczności. W polskim prawie tylko niektóre zawody medyczne mają wpisaną klauzulę sumienia w ustawy regulujące wykonywanie tych zawodów. Są nimi lekarze, lekarze dentyści, pielęgniarki i położne. Farmaceuci nie należą do tej grupy (co ma również związek ze wspomnianą decyzją Trybunału Europejskiego, jednakże część z nich korzysta z klauzuli, powołując się na przysługujące im prawa człowieka (wpisane w Konstytucję RP czy Konwencję Europejską). Brak klauzuli sumienia wpisanej w ustawę zawodową może powodować skutki prawne w postaci np. zwolnienia z pracy farmaceuty, który nie wydał pacjentce środka antykoncepcyjnego. Od takiej decyzji jednak farmaceuta może się odwołać po wyczerpaniu „drabiny odwoławczej” do Trybunału Konstytucyjnego w Polsce czy Trybunału Europejskiego.

Lekarze oraz lekarze dentyści gwarancje prawne wolności sumienia mają wpisane w art. 39 ustawy o zawodach lekarza i lekarza dentysty z 5 grudnia 1996 r., który brzmi: „Lekarz może powstrzymać się od wykonania świadczeń zdrowotnych niezgodnych z jego sumieniem (z zastrzeżeniem art. 30), z tym że ma obowiązek wskazać realne możliwości uzyskania tego świadczenia u innego lekarza lub w podmiocie leczniczym oraz uzasadnić i odnotować ten fakt w dokumentacji medycznej. Lekarz wykonujący swój zawód na podstawie stosunku pracy lub w ramach służby ma ponadto obowiązek uprzedniego powiadomienia na piśmie przełożonego" [14]. Wspomniany art. 30 wskazuje na sytuację, gdy lekarz odmawiając udzielenia świadczenia, nie może powołać się na klauzulę sumienia. Artykuł ten dotyczy ratowania życia i zdrowia ludzkiego oraz opisuje przypadki, w których zwłoka w udzieleniu pomocy lekarskiej mogłaby grozić niebezpieczeństwem utraty życia, ciężkiego uszkodzenia ciała lub ciężkiego rozstroju zdrowia, a także inne przypadki niecierpiące zwłoki. Zastrzeżenie co do stosowania klauzuli sumienia związane z tym artykułem wynika z uznania w hierarchii dóbr osobistych, życia ludzkiego (pacjenta) jako wartości nadrzędnej wobec dobra, jakim jest wolność (w tym wypadku lekarza).

Artykuł 39 nakłada także na lekarza wykonującego zawód w stosunku służbowej zależności obowiązek uprzedniego zawiadomienia na piśmie przełożonego lekarza o odstąpieniu od leczenia pacjenta. Zawiadomienie to jest tylko wymogiem formalnym, gdyż do realizacji klauzuli sumienia nie jest wymagane uzyskanie zgody od przełożonego. Po złożeniu zawiadomienia lekarz ma więc pełne prawo do skorzystania z klauzuli sumienia, nawet gdy przełożony nie popiera jego poglądów moralnych.

Jednakże w przypadku odstąpienia od udzielania świadczenia przez lekarza powołującego się na klauzulę sumienia wymagane jest spełnienia dodatkowego warunku, tj. wskazanie realnych możliwości uzyskania świadczenia u innego świadczeniodawcy. Przepis ten jest niezgodny z linią orzeczniczą Trybunału Europejskiego. Trybunał w 2011 r. wydał orzeczenie, w związku ze skargą obywatelki Alicji Tysiąc, że odmowa lekarza wydania skierowania na badania prenatalne pozbawiła ją możliwości legalnej aborcji. Trybunał uznał, że państwo przyznając pracownikom ochrony zdrowia klauzulę sumienia, musi jednocześnie zagwarantować pacjentom możliwość uzyskania świadczenia w innym miejscu. Obowiązek wskazania tego miejsca powinien więc spoczywać na strukturach państwowych stojących w centrum systemu zdrowia, a nie na lekarzu [15]. Jest to uzasadnione tym bardziej, że art. 39 godzi w sens sprzeciwu sumienia, gdyż lekarz odmawiając udzielenia świadczenia, musi jednocześnie pomóc w jego wykonaniu poprzez wskazanie innego świadczeniodawcy, co przecież nie jest zgodne z jego sumieniem.

Prawo do klauzuli sumienia w Polsce posiadają również pielęgniarki i położne. Wpisane jest ono w art. 12 ust. 2 i następny ustawy z dnia 15 lipca 2011 r. o zawodach pielęgniarki i położnej [16]. Pielęgniarka i położna mogą odmówić wykonania zlecenia lekarskiego oraz wykonania innego świadczenia zdrowotnego niezgodnego z ich sumieniem, podając niezwłocznie przyczynę odmowy na piśmie przełożonemu lub osobie zlecającej, chyba że zachodzi stan nagłego zagrożenia zdrowotnego. Dalsze wymagania związane z korzystaniem z klauzuli 
sumienia przypominają przepisy lekarzy, a więc pielęgniarka i położna w przypadku odstąpienia od realizacji świadczeń zdrowotnych mają obowiązek niezwłocznego uprzedzenia pacjenta o takiej odmowie i wskazania realnych możliwości uzyskania tego świadczenia u innej pielęgniarki, położnej lub w podmiocie leczniczym, a także mają obowiązek uzasadnić i odnotować ten fakt w dokumentacji medycznej. Praktyka pokazuje jednak, że funkcjonowanie systemu pod względem respektowania klauzuli sumienia w grupie zawodowej pielęgniarek jest niewłaściwe, skoro według badań aż 1/3 z nich podczas realizacji świadczenia zdrowotnego była zmuszona podjąć decyzję niezgodną z własnym sumieniem [17].

W przypadku pielęgniarek i położnych, podobnie jak w przypadku lekarzy, również istnieje problem niezgodności przepisu o konieczności wskazywania możliwości uzyskania przez pacjenta świadczenia w innym miejscu ze wspomnianym wyrokiem Trybunału Europejskiego z 28 listopada $2011 \mathrm{r}$. Postuluje się więc stworzenie takich procedur prawnych i organizacyjnych, w których istniałaby możliwość zagwarantowania realizacji praw pacjenta do korzystania z tych świadczeń, które mimo iż są wątpliwe moralnie dla pracownika podmiotu leczniczego, to zostaną zrealizowane w ramach systemu opieki zdrowotnej, przy zachowaniu autonomii moralnej pracownika medycznego, w tym pielęgniarki i położnej [18]. Celem stworzenia wspomnianych procedur jest sytuacja w której realizacja klauzuli sumienia przez pracowników nie będzie ograniczać pacjentom dostępu do świadczeń zdrowotnych [19].

\section{OKOLICZNOŚCI STOSOWANIA KLAUZULI SUMIENIA W POLSKIM SYSTEMIE OCHRONY ZDROWIA}

Przy wprowadzaniu ograniczeń wolności sumienia i wyznania powinny być brane pod uwagę dylematy moralne związane z rozwojem nauk technicznych i medycznych. Niepodejmowanie bowiem przez jednostkę jakichś działań czy brak sprzeciwu wobec innych może w istocie oznaczać odrzucenie wartości stanowiących podstawę jakiegoś wyznania lub systemu przekonań. Państwo winno zatem umożliwić jednostce ochronę jej wewnętrznej autonomii przy jednoczesnym zapewnieniu realizacji świadczeń zdrowotnych.

Zgromadzenie Parlamentarne Rady Europy 7 października 2010 r. wydało rezolucję $1763 \mathrm{w}$ sprawie sprzeciwu sumienia w opiece medycznej, wyrażając w niej zalecenia co do stosowania klauzuli w krajach członkowskich Rady Europy. Zgromadzenie wskazuje, że każde państwo ma w tym zakresie podwójne zobowiązanie: wobec pracowników ochrony zdrowia (prawo do wolności myśli, sumienia, wyznania) i wobec pacjentów (prawo do legalnej opieki medycznej). Winno zatem stworzyć wyczerpujące i przejrzyste regulacje prawne definiujące i zapewniające możliwość stosowania klauzuli przez świadczeniodawców. Regulacje te powinny zagwarantować prawo do klauzuli sumienia w odniesieniu do uczestnictwa w procedurach budzących wątpliwości, a także zapewniać, że pacjenci zostaną poinformowani o zaniechaniu udzielenia świadczenia w stosownym czasie oraz zostaną skierowani do innego świadczeniodawcy, gdzie uzyskają oczekiwane świadczenie, szczególnie w przypadkach nagłych.

Korzystanie z klauzuli sumienia w opiece zdrowotnej dotyczy wszystkich kontrowersyjnych kwestii związanych z początkiem i końcem ludzkiego życia, a więc procedurą zapłodnienia in vitro, zabiegów aborcji dozwolonej przez prawo, stosowania procedur związanych z eutanazją. Należy dodać, że nikt nie może uczestniczyć w eksperymencie medycznym bez dobrowolnie wyrażonej zgody, dotyczy to też pracowników medycznych (jako strony wykonującej eksperyment), co też chroni ich przed zaangażowaniem $\mathrm{w}$ badania naukowe sprzeczne z sumieniem.

W praktyce klauzula sumienia w Polsce w odniesieniu do lekarzy dotyczy najczęściej zabiegów legalnej aborcji oraz wystawiania skierowań na badania prenatalne będące podstawą jej przerywania. Inne wskazania to procedura in vitro, czy odmowa przepisania środków poronnych. Eutanazja nie jest dozwolona w Polsce zarówna w lekarskich przepisach etycznych [20], jak i prawnych [21].

Zgodnie z art. 31 Kodeksu etyki lekarskiej lekarzowi nie wolno stosować eutanazji ani pomagać choremu w popełnieniu samobójstwa. W § 1 art. 150 Kodeksu karnego czytamy: „Kto zabija człowieka na jego żądanie i pod wpływem współczucia dla niego, podlega karze pozbawienia wolności od 3 miesięcy do lat 5”. Jednak § 2 przewiduje że: „W wyjątkowych wypadkach sąd może zastosować nadzwyczajne złagodzenie kary, a nawet odstąpić od jej wymierzenia".

Zgodnie z art. 150 Kodeksu karnego eutanazja jest uprzywilejowanym typem zabójstwa (typ charakteryzujący się zmniejszoną szkodliwością społeczną) z możliwością niekarania oskarżonego. Konstrukcja prawna „zabójstwa na żądanie” umożliwiająca depenalizację bierze pod uwagę postawę lekarza, którego przekonania nakazywały mu dokonania czynu eutanatycznego ze względu na współczucie wobec cierpienia chorego. Ocena czynu wpływająca na orzeczenie o karze należy do składu orzekającego i w różnych przypadkach może być odmienna. Nie można zatem założyć, że czyn eutanatyczny nie zostanie ukarany. Należy dodać, że w praktyce orzeczniczej Trybunału Europejskiego uznano, że przekonania dotyczące pomocy w samobójstwie nie stanowią realizacji wolności sumienia $\mathrm{z}$ art. 9, ale realizację zasady autonomii jednostki $\mathrm{z}$ art. 8 Konwencji europejskiej [22]. Natomiast w ramach niepotęgowania cierpienia w stanach terminalnych dozwolonym narzędziem etycznym dostępnym dla lekarza w Polsce jest art. 32 Kodeksu etyki lekarskiej [20].

Art. 32 ust. 1 i 2 Kodeksu etyki lekarskiej: „w stanach terminalnych lekarz nie ma obowiązku podejmowania i prowadzenia reanimacji lub uporczywej terapii i stosowania środków nadzwyczajnych. decyzja o zaprzestaniu reanimacji należy do lekarza i jest związana z oceną szans leczniczych" [20].

Wynika z niego, że lekarz w Polsce nie musi narażać swoich pacjentów na nadmierne cierpienie związane z śmiertelną chorobą, a decyzję o zaprzestaniu reanimacji podejmuje samodzielnie stosując kryteria medyczne, a nie jak w przypadku eutanazji pod wpływem żądania chorego, czy współczucia. 
Najczęstsza okolicznością korzystania z klauzuli sumienia jest w Polsce odmowa wykonania aborcji. Zgodnie z ustawą z dnia 7 stycznia 1993 r. o planowaniu rodziny, ochronie płodu ludzkiego i warunkach dopuszczalności przerywania ciąży aborcja może być dokonana wyłącznie przez lekarza w trzech przypadkach - przy czym dwa z nich są stwierdzane w opinii lekarza, zaś jedna jest stwierdzona urzędowo [22]. Przesłanki i okoliczności legalnej aborcji zostały uregulowane w art. 4a. Przesłanki medyczne, tj. gdy ciąża stanowi zagrożenie dla życia lub zdrowia kobiety ciężarnej lub badania prenatalne czy inne przesłanki medyczne wskazują na duże prawdopodobieństwo ciężkiego i nieodwracalnego upośledzenia płodu (albo nieuleczalnej choroby zagrażającej jego życiu), są stwierdzane przez lekarza, który nie może brać udziału w usunięciu ciąży wówczas, gdy okoliczność dotyczy choroby płodu. Należy dodać, że okoliczności związane ze zdrowiem i życiem matki mogą być wykorzystane aż do końca trwania ciąży, zaś związane z upośledzeniem bądź chorobą płodu aż chwili osiągnięcia przez płód zdolności do samodzielnego życia poza organizmem kobiety ciężarnej (art. 4a ust. 1 i 2 ustawy o planowaniu rodziny...). Trzecia ustawowa przesłanka usunięcia ciąży zachodzi wówczas, gdy powstanie uzasadnione podejrzenie, że ciąża powstała w wyniku czynu zabronionego, tj. kazirodztwa bądź gwałtu czy też obcowania z małoletnią poniżej 15. r.ż. [21], co stwierdza prokurator (art. 4a ustawy).

Przestępstwa z art. 201 (kazirodztwo - obcowanie płciowe z zstępnym, wstępnym, przysposobionym, przysposabiającym, bratem lub siostrą), art. 197 (gwałt, w tym gwałt małoletniej poniżej lat 15 - doprowadzenia do obcowania płciowego przemocą, groźbą bezprawna lub podstępem ), art. 200 (obcowanie lub czynność seksualna z małoletnią poniżej lat 15) ustawy z dnia 6 czerwca 1997 r. - Kodeks karny (Dz. U. 1997 r., Nr 88, poz. 553).

Na tej podstawie może dojść do usunięcia ciąży, jeżeli od jej początku nie upłynęło więcej niż 12 tygodni. We wszystkich tych przypadkach do przerwania ciąży wymagana jest pisemna zgoda kobiety, a gdy małoletnia nie ma ukończonych 13 lat, wyraża swoją opinię, zaś zgodę (bądź jej brak) zamiast niej wyrażają przedstawiciele ustawowi (rodzic, opiekun prawny) oraz sąd opiekuńczy. Małoletnia, która ma ukończone 13 lat, oraz kobieta ubezwłasnowolniona wyrażają pisemną zgodę oraz wymagana jest zgoda ich przedstawicieli ustawowych. $\mathrm{W}$ razie niezgody małoletniej powyżej lat 13 o dalszym losie ciąży zadecyduje sąd opiekuńczy. Lekarz może nie podjąć się dokonania aborcji w przypadku stwierdzenia wad płodu oraz gdy ciąża powstała w wyniku czynu zabronionego. Nie może natomiast skorzystać z klauzuli sumienia wówczas, gdy istnieje zagrożenia życia kobiety ciężarnej, z uwagi na zobowiązanie ratowania w pierwszej kolejności jej życia, co wynika przede wszystkim z ustawy o zawodzie lekarza. Jak wcześniej było wspomniane, ratowanie życia ludzkiego jest wyjątkiem od możliwości stosowania klauzuli sumienia (art. 39 w związki z art. 30 ustawy o zawodzie lekarza). Stwierdzenie ciężkiej choroby płodu jest przesłanka przerywania ciąży, a jej stwierdzenie należy do lekarza i wymaga wykonania badań prenatalnych. Nieskierowanie na badania prenatalne może być powodem sądowych roszczeń o zadośćuczynienie za doznaną krzywdę z tytułu tzw. złego urodzenia (wrongful bright), wówczas gdy rodzi się dziecko chore wskutek zawinionego przez lekarzy zaniechania diagnostyki, które uznają zarówno sądy krajowe [23], jak i Trybunał Europejski [24]. Nadto, jak wynika z art. 38 ust. 3 KEL, „lekarz ma obowiązek zapoznać pacjentów z możliwościami współczesnej genetyki lekarskiej, a także diagnostyki i terapii przedurodzeniowej". Przekazując powyższe informacje, lekarz powinien poinformować o ryzyku związanym z przeprowadzeniem badań przedurodzeniowych. Niedopuszczenie do diagnostyki i terapii przedurodzeniowej jest zdaniem trybunału łamaniem art. 3 Konwencji o prawach człowieka jako nieludzkie i poniżające traktowanie. Na gruncie prawa polskiego niedopuszczenie do diagnostyki przedurodzeniowej godzi w prawo pacjenta do informacji, w którego zakresie jest prawo do informacji o metodach diagnostycznych, konsekwencjach ich zastosowania bądź zaniechania [25]. Także ustawa z dnia 7 stycznia 1993 r. o planowaniu rodziny, ochronie płodu ludzkiego i warunkach dopuszczalności przerywania ciąży przewiduje szczególne zobowiązania, jednak nie dla lekarza, ale dla organów administracji rządowej oraz samorządu terytorialnego, które są zobowiązane zapewnić swobodny dostęp do informacji i badań prenatalnych, szczególnie wtedy, gdy istnieje podwyższone ryzyko bądź podejrzenie wystąpienia wady genetycznej lub rozwojowej płodu albo nieuleczalnej choroby zagrażającej życiu płodu (art. 2 ust. 2a).

Prawo do korzystania z klauzuli sumienia przysługuje nie tylko osobom fizycznym, ale i prawnym. Jeśli szpital wypracuje sobie nieformalny status „broniącego życie od chwili poczęcia”, może zobowiązać lekarzy w nim pracujących do zaniechania dozwolonych przez prawo procedur aborcyjnych. Z orzeczeń Europejskiego Trybunału wynika, że lekarz, który naruszyłby standardy etyczne określone przez pracodawcę (np. szpital katolicki), wskutek czego zwolniono by go z pracy, nie jest chroniony przez Konwencję praw człowieka [26]. Jakkolwiek państwa muszą szczegółowo badać, czy nie są naruszone postanowienia art. 8 (prawo do prywatności) czy art. 10 (wolność wyrażania opinii) Konwencji europejskiej. Co do korzystania z klauzuli sumienia przez osobę prawną, jaką jest np. szpital, zdania są podzielone. Przeciwnicy podnoszą, że sumienie dotyczy tylko jednostek oraz ich konkretnych poglądów i nie istnieje instytucja „zbiorowego sumienia”. Jednak związku z tym, że sumienie jest często związane z wyznawaną wiarą, której praktykowanie jest realizacją art. 9 ust. 2 (np. realizacja przykazania „nie zabijaj” z dekalogu wobec dzieci nienarodzonych), można uznać, że zbiorowość wierzących może mieć zasadniczo tak samo ukształtowane sumienie i jako grupa domagać się respektowania wolności sumienia poprzez stosowanie klauzuli.

\section{ZAKOŃCZENIE}

Podsumowując, można stwierdzić, że lekarze, lekarze dentyści, pielęgniarki i położne nie mają zapewnionej pełnej ochrony wolności sumienia zgodnej z interpretacją Rady Europy. 
Wynika to z istnienia dodatkowego prawnego wymogu wskazania osoby, która winna je zastąpić w pracy wówczas, gdy korzystają z klauzuli sumienia. Jest to zobowiązanie do czynu niezgodnego z sumieniem czy przekonaniami, a wiec czynności moralnie niedopuszczalnej. Tymczasem, jak wskazuje Rada Europy, to państwo, nie pracownik medyczny, jest zobowiązane tak zorganizować system opieki zdrowotnej, aby jednocześnie zapewnić respektowanie zarówno wolności sumienia personelu medycznego, jak i praw pacjentów do świadczeń opieki zdrowotnej. Państwo polskie powinno zweryfikować ustawodawstwo dotyczące prawa wykonywania zawodów medycznych w zakresie zgodności z wolnością z art. 9 Konwencji europejskiej, ze względu na swoje zobowiązania w tym zakresie i ryzyko odpowiedzialności za brak przestrzegania postanowień Konwencji europejskiej. W ślad za tym wskazane jest stworzenie systemowych procedur umożliwiających korzystanie z klauzuli sumienia pracownikom medycznym oraz zapewniających należyty dostęp do świadczeń opieki zdrowotnej pacjentom. Brak odrębnej regulacji dla pozostałych zawodów medycznych nie oznacza braku możliwości powołania się na wolności z art. 9 Konwencji europejskiej.

\section{PIŚMIENNICTWO}

1. Konstytucja Rzeczypospolitej Polskiej z dnia 2 kwietnia 1997 r. Dz. U. 1997 nr 78 poz. 483 z późn. zm.

2. Prawo Konstytucyjne. Ed.Z. Witkowski. Wyd. TNOiK, Toruń 2013,63-64.

3. Janyga $W$ : Wolność sumienia i wyznania wobec wyzwań pluralizmu religijnego (na tle wyroku Federalnego Sądu Konstytucyjnego Niemiec z 24 IX 2003r.). Państwo i Prawo. 2004 (10), 84.

4. Pietrzak M.: Demokratyczne świeckie państwo prawa. Liber, Warszawa 1999, 80.

5. Nawrot O.: Klauzula sumienia w zawodach medycznych w świetle standardów Rady Europy. Zeszyty Prawnicze. Biura Analiz Sejmowych Kancelarii Sejm. 2012, 3 (35), 11-29.

6. Konwencja o ochronie praw człowieka i podstawowych wolności. Komentarz do artykułów 1-18, t. I. Ed: L. Garlicki. Wyd. C.H. Beck, Warszawa $2010,55$.
7. Murdoch J:: Ochrona prawa do wolności myśli, sumienia i wyznania w EKPCiPW. Podręcznik praw człowieka Rady Europy. Rada Europy, Strasburg 2012, 18-23.

8. Nowicki M.A.: Wokół konwencji europejskiej. Komentarz do Europejskiej Konwencji praw człowieka. Lex a Wolters Kluwer bussines, Warszawa 2013, http://www.profinfo.pl/img/401/pdf40154306_4.pdf (03.01.2015).

9. Wyrok ETSC z 25 maja 1993 r. (sprawa Kokinakis przeciwko Grecji, nr 14307/88).

10. Wiśniewski A.: Koncepcja marginesu oceny w orzecznictwie Europejskiego Trybunału praw człowieka, Gdańsk 2008.

11. Orzeczenie ETPC z 7 lipca 2011 r. w sprawie Bayatyan v. Armenia nr 23459/03.

12. Orzeczenie ETPC z 18 lutego 1993r., skarga nr 20747/92.

13. Decyzja ETPC z 2 listopada 2001 r., skarga nr 49853/99.

14. Ustawa z dnia 5 grudnia 1996 r. o zawodzie lekarza i lekarza dentysty. Dz. U. 1997 nr 28 poz. 152 z późn. zm.

15. Wyrok ETPC z 28 listopada 2011 r., skarga nr 27617/04.

16. Ustawa z dnia 15 lipca 2011 r. o zawodach pielęgniarki i położnej. Dz. U. z 2011 r., Nr 174, poz. 1039.

17. Jarmoluk P., Ikwanty K., Durak K., Tetych J.: Klauzula sumienia w praktyce pielęgniarki, w: Lubelski Kongres Studenckich Kół Naukowych Tygiel 2009 - czyli jak rozwijać naukę? Lublin, 23-24 września 2009. Eds: J. Caban, M. Szala M. Wydawnictwo Politechniki Lubelskiej, Lublin 2009.

18. Dobrowolska B., Cegiełko P.: Instytucja klauzuli sumienia w zawodzie pielęgniarki i położnej. www.ptb.org.pl/pdf/dobrowolska_cegielko_klauzula_1.pdf|'(03.01.2015).

19. Wyrok ETPCz z dnia 26 maja 2011 r. w sprawie nr 27617/04, R.R. vs. Polska.

20. Kodeks etyki lekarskiej - art. 31.

21. Ustawa z dnia 6 czerwca 1997 r. - Kodeks karny. Dz. U. 1997 r. Nr 88 poz. 553.

22. Sprawa Pretty przeciwko Zjednoczonemu Królestwu, 29 kwietnia 2002 r. gdzie uznano, że opinia na temat eutanazji nie stanowi przekonań religijnych czy filozoficznych, ale jest wyrazem wewnętrznej autonomii jednostki rozpatrywanej z art. 8 konwencji europejskiej - prawo do poszanowania życia prywatnego i rodzinnego.

23. Ustawa z dnia 7 stycznia 1993 r. o planowaniu rodziny, ochronie płodu ludzkiego i warunkach dopuszczalności przerywania ciąży. Dz. U. z 1993 r. Nr 17, poz. 78.

24. Orzeczenie Sądu Najwyższego (PL) z 6 maja 2010 r. (II CSK 580/09).

25. Sprawa R.R. przeciwko Polsce nr 27617/04, orzeczenie z 26 maja 2011 r. - zadośćuczynienie za doznaną krzywdę zsądzono w wysokości 45000 euro za złamanie art. 3 Konwencji - nieludzkie i poniżające traktowanie.

26. Art. 9 ust. 2 Ustawy z dnia 6 listopada 2008 r. o prawach pacjenta i Rzeczniku Praw Pacjenta (Dz. U. z 2009 r. Nr 52, poz. 417).

27. Decyzja ETPC z 6 września 1989 r., skarga nr 12242/86, wyrok z 20 października $2009 \mathrm{r}$. 